\title{
Absence of mutations in four genes encoding for congenital cataract and expressed in the human brain in Tunisian families with cataract and mental retardation
}

Manèl Chograni ${ }^{1}$, Myriam Chaabouni ${ }^{1,2}$, Faouzi Mâazoul ${ }^{2}$, Hedi Bouzid ${ }^{3}$, Abdelhafid Kraiem $^{4}$ and Habiba B Bouhamed Chaabouni ${ }^{1,2^{*}}$

\begin{abstract}
Background: To identify the genetic defect associated with autosomal recessive congenital cataract (ARCC), mental retardation (MR) and ARCC, MR and microcephaly present in most patients in four Tunisian consanguineous families.

Methods: We screened four genes implicated in congenital cataract by direct sequencing in two groups of patients; those affected by ARCC associated to MR and those who presented also microcephaly. Among its three genes PAX6, PITX3 and HSF4 are expressed in human brain and one gene LIM2 encodes for the protein MP20 that interact with the protein galectin-3 expressed in human brain and plays a crucial role in its development. All genes were screened by direct sequencing in two groups of patients; those affected by ARCC associated to MR and those who presented also microcephaly.

Results: We report no mutation in the four genes of congenital cataract and its flanking regions. Only variations that did not segregate with the studied phenotypes (ARCC associated to MR, ARCC associated with MR and microcephaly) are reported. We detected three intronic variations in PAX6 gene: IVS4 -274insG (intron 4), IVS12 $-174 G>A$ (intron12) in the four studied families and IVS4 -195G>A (intron 4) in two families. Two substitutions polymorphisms in PITX3 gene: C.439 C>T (exon 3) and C.930 C>A (exon4) in one family. One intronic variation in HSF4 gene: IVS7 +93C >T (intron 7) identified in one family. And three intronic substitutions in LIM2 gene identified in all four studied families: IVS2 -24A>G (intron 2), IVS4 +32C >T (intron 4) and C.*15A>C (3'-downstream sequence).

Conclusion: Although the role of the four studied genes: PAX6, PITX3, HSF4 and LIM2 in both ocular and central nervous system development, we report the absence of mutations in all studied genes in four families with phenotypes associating cataract, MR and microcephaly.
\end{abstract}

\section{Background}

Congenital cataracts show considerable clinical and locus heterogeneity and represent one of the major causes of vision loss world-wide [1]. Cataracts can be isolated or can occur in association with a large number of different metabolic diseases or genetic syndromes [2].

\footnotetext{
* Correspondence: habiba.chaabouni@rns.tn

'University Tunis Elmanar, Faculté de Médecine de Tunis, Laboratoire

Génétique Humaine, Tunis, Tunisia

Full list of author information is available at the end of the article
}

Non syndromic congenital cataract has an estimated frequency of 1-6 per 100,000 live births [3].

More than 20 genes have been implicated in human congenital cataract, most of them are responsible for the autosomal dominant trait than the autosomal recessive one $[4,5]$ in these can be divided into two clusters according to the stage of lens development at which they are involved. The first group contains genes that determine lens structure and genes related to structure, including crystallins, Bfsp, connexions and MIP [4-6].

\section{Biomed Central}


Among genes encoding for membrane proteins (MIP), LIM2 gene (lens intrinsic membrane protein-2) involved in autosomal recessive congenital cataract $[7,8]$. It encodes an abundant integral lens membrane protein MP20 which is a new regulatory protein important for mammalian lens fiber cell junctional formation [9]. Lens-specific MP20 is classified as a member of the PMP22/EMP/MP20 subfamily of tetraspanins [10] and adds to a growing list of ligands of galectin-3[11], a known adhesion modulator that is expressed by microglial cells of adult brain [12] and contributes to injury in the deep gray matter areas of the brain [13].

The second group of genes including transcription factors PAX6, PITX3 and HSF4 member of the heat shock transcription factor (HSF) family [6]. These three transcription factors are expressed in the human brain and led to autosomal dominant or autosomal recessive congenital cataract or both.

PAX6 gene (Paired box homeotic gene 6), 11p13, a paired box transcription factor, was described the among the wide set of genes responsible for autosomal dominant congenital cataract (ADCC) [14] that is expressed in the developing eye, brain, spinal cord and pancreas and seems to play a crucial role in the developing of the central nervous system by transcriptional regulation of various target genes $[15,16]$.

PITX3 gene (Pituitary homeobox gene 3) mapped on 10q24.32, is also responsible for ADCC and expressed in the developing lens, skeletal muscle, and dopaminergic neurons of the substantia nigra in the brain [17].

HSF4 gene (Heat-shock transcription factor 4) localized on 16q21-q22.1 and for which mutations are associated with both autosomal dominant [18] and autosomal recessive congenital cataract (ARCC) [19-21]. In the human, HSF4 is widely expressed, especially in the heart, brain, skeletal muscle, lung and pancreas [22,23].

Based on these observations, we analysed the four genes: LIM2, PAX6, PITX3 and HSF4 in four consanguineous unrelated Tunisian families with ARCC associated with mental retardation (MR) for two patients belonging to the same family and ARCC associated to MR and microcephaly for the others from the four studied families.

\section{Methods}

\section{Subjects and sample collection}

We evaluated seventeen patients (7 parents, 10 patients including 9 affected and 1 normal from family F1) belonging to four Tunisian unrelated families (Figure 1) recruited from Congenital and Hereditary Disorders Department at Charles-Nicolle Hospital (Tunis, Tunisia).

All four families were of Tunisian origin and were enrolled in a genetic research program in the laboratory

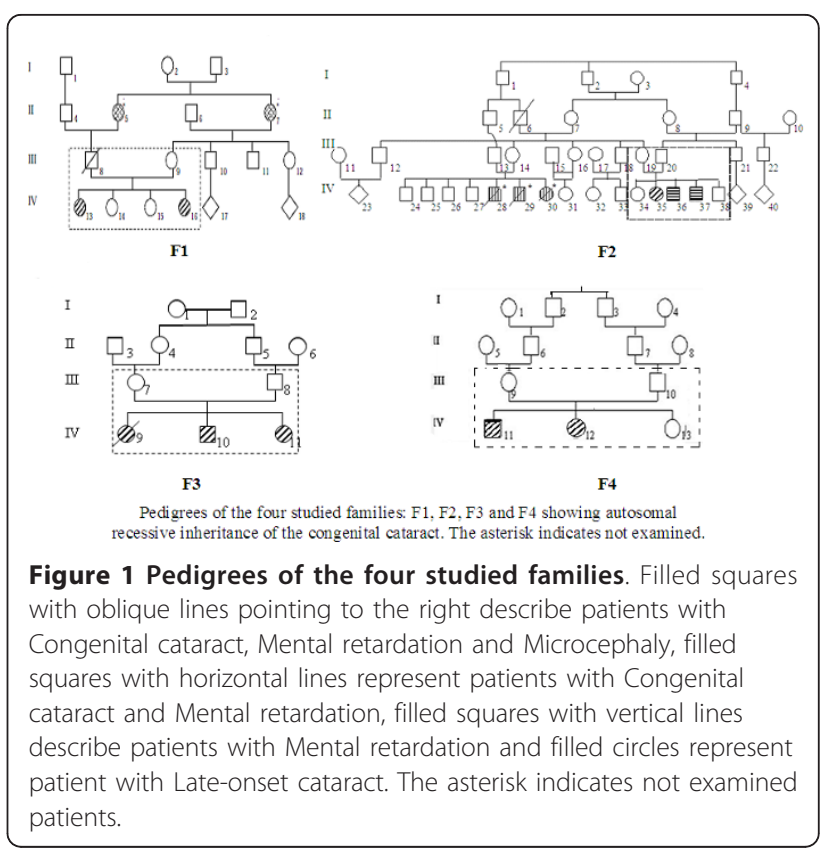

of Human Genetics, in the faculty of medicine (Tunis, Tunisia) because of two affected brothers belonging to family F2 with ARCC and MR and seven affected patients from the four studied families (F1, F2, F3, F4) with ARCC, MR and microcephaly.

The nine patients ( 5 males, 4 females) were born from healthy and consanguineous parents. Pedigrees' patterns are concordant with autosomal recessive inheritance for the four families (Figure 1). Their mean age was 23 years, ranging from 8 to 41 years. We noted that the father from family F1 was dead after au traumatic accident. Cataracts were reportedly present since birth in all patients. None had glaucoma before or after the extraction of cataracts.

The cataracts were of the posterior polar type and bilateral in all patients except of the affected child IV11 belonging to family F4. All patients had undergone cataract extraction early in life. Visual acuity was preserved in all patients except of the affected child IV12 from family F4 who showed decreased visual acuity and alteration of the pigment epithelium. We denoted the presence of retinal dystrophy and strabismus in patient IV16 belonging to family F1. We underlined also the presence of nystagmus, microphthalmia and strabismus in patient IV11 from family F3 whose brother IV10 presented also microphthalmia.

Significant physical disability became apparent for all patients by the age of 15 to 18 months when they failed to walk. They also had a significant delay in speech development. In fact, the nine affected patients were developmentally delayed with mild to moderate mental retardation with no dysmorphic features. Microcephaly 
was present in all of them except the two brothers IV36 and IV37 belonging to family F2. Additional features are shown in table 1.

Magnetic resonance imaging (MRI) of the brain was normal in all screened patients except for the presence of a small ischemic parietal lesion in patient IV16 from family F1 and the presence of Dandy-Walker anomaly with thinning of corpus callosum in patients IV10 and IV11, belonging to family F3, whose sister IV9 showing MR, bilateral congenital cataract, microcephaly and epilepsy was dead at 3 years.

Biological investigations (karyotyping with R-banding) revealed normal karyotypes; 46,XX for females, 46,XY for males (600 bands resolution) and normal metabolic screening including Fehling reaction and thin layer chromatography of reducing sugars, plasmatic amino acid and urine organic acid chromatography for all patients.

Genomic DNA of affected and unaffected members (10 siblings, 7 parents) was extracted from peripheral blood leukocytes by the standard proteinase-K extraction consisting on: lysis of red blood cells by RBC (Red Blood Cells) Lysis Buffer (155 mM NH4Cl, $10 \mathrm{mM}$ KHCO3, 0.5 EDTA, pH 7.5) and white blood cells by a WBC (White Blood Cells) Lysis Buffer (1 mM NaEDTA, $5 \mathrm{mM}$ Tris $\mathrm{HCl} \mathrm{pH} \mathrm{7.5),} \mathrm{treatment} \mathrm{of} \mathrm{the} \mathrm{lysate}$ with a mixture of detergent composed of SDS (Sodium Dodecyl Sulfate or sacrosyl and proteinase K) in order to liberate the DNA and digest the associated proteins, precipitation of the DNA in the form of filaments by absolute ethanol and finally diluation of the DNA in T10E1 Buffer (Tris $10 \mathrm{mM}$, EDTA 0.1-1 mM), and stored in $10 \mathrm{ml}$ Vacuum tube sterile containing $100 \mu \mathrm{l}$ of 0.1 M EDTA.K3.

\section{Patients and parents for minors gave informed consent}

In this study, the researches carried out on human are in compliance with the Helsinki Declaration and ethics committee Charles Nicolle hospital, Tunis has given approval for this study.

Table 1 Clinical features of the 9 affected patients belonging to the four studied families: F1, F2, F3 and F4

\begin{tabular}{|c|c|c|c|c|c|c|c|c|c|}
\hline Familles & $\mathrm{F} 1$ & & F2 & & & F3 & & F4 & \\
\hline Patients & IV13 & IV16 & IV35 & IV36 & IV37 & IV10 & IV11 & IV11 & IV12 \\
\hline Weigt (Kg) & $\mathrm{N}$ & $\mathrm{N}$ & $\mathrm{N}$ & $\mathrm{N}$ & $\mathrm{N}$ & $\mathrm{N}$ & $\mathrm{N}$ & $\mathrm{N}$ & $\mathrm{N}$ \\
\hline Height $(\mathrm{cm})$ & $\mathrm{N}$ & $\mathrm{N}$ & $\mathrm{N}$ & $\mathrm{N}$ & $N$ & $\mathrm{~N}$ & $\mathrm{~N}$ & $\mathrm{~N}$ & $\mathrm{~N}$ \\
\hline Cataract & unilateral & bilateral & bilateral & bilateral & bilateral & bilateral & bilateral & unilateral & bilateral \\
\hline $\begin{array}{l}\text { Age of } \\
\text { cataract }\end{array}$ & 3 years & 3 years & 2 years & 3 years & 2 years & 6 months & 1 year & 3 years & 3 years \\
\hline Microcephaly & $-5.5 \mathrm{DS}$ & -6.7 DS & $-2.8 \mathrm{DS}$ & $\mathrm{N}$ & $\mathrm{N}$ & $-3.5 \mathrm{DS}$ & -3 DS & $-5.6 \mathrm{DS}$ & $-3.8 \mathrm{DS}$ \\
\hline$\overline{M R}$ & moderate & moderate & moderate & moderate & mild & moderate & moderate & moderate & moderate \\
\hline Age of MR & 3 years & 3 years & 2 years & 3 years & 2 years & 1 year & 3 years & 3 years & 3 years \\
\hline \multirow[t]{2}{*}{$\begin{array}{l}\text { Developmental } \\
\text { delay }\end{array}$} & \multirow{2}{*}{\multicolumn{2}{|c|}{$\begin{array}{l}\text {-Could not learn nor write. } \\
\text {-Troubles of eloculation } \\
\text {-Running all alone. }\end{array}$}} & \multirow[t]{2}{*}{$\begin{array}{l}\text {-Walked at age of } 2 \\
\text { years. } \\
\text {-Difficult to shake } \\
\text { hands and close } \\
\text { eyes. }\end{array}$} & \multirow[t]{2}{*}{$\begin{array}{l}\text {-Walked at } \\
2 \text { years. } \\
\text {-Spoke at } 5 \\
\text { years. } \\
\text {-Absence } \\
\text { of } \\
\text { anatomy. }\end{array}$} & \multirow[t]{2}{*}{$\begin{array}{l}\text { Difficult } \\
\text { to learn. }\end{array}$} & \multicolumn{2}{|c|}{$\begin{array}{l}\text {-Spoke at } 2 \text { years. } \\
\text {-Speech with } \\
\text { monosyllabic words. }\end{array}$} & \multirow{2}{*}{\multicolumn{2}{|c|}{$\begin{array}{l}\text { Walked and spoke at ages of } 2 \\
\text { years. }\end{array}$}} \\
\hline & & & & & & \multicolumn{2}{|c|}{$\begin{array}{l}\text { IV10 -Sit with } \\
\text { supports since } 5 \\
\text { months. } \\
\text { IV } 10 \text {-Walk with } \\
\text { assistance gained. }\end{array}$} & & \\
\hline$\overline{M R I}$ & $N$ & $\begin{array}{l}\text { Small parietal } \\
\text { ischemic lesion }\end{array}$ & $\mathrm{N}$ & $\mathrm{N}$ & $N$ & \multicolumn{2}{|c|}{$\begin{array}{l}\text {-Anomaly if Dandy- } \\
\text { Walker. } \\
\text {-Thinning of corpus } \\
\text { callosum. }\end{array}$} & $N$ & $\mathrm{~N}$ \\
\hline Others & $\begin{array}{l}\text { Slight axial } \\
\text { hypotonia }\end{array}$ & $\begin{array}{l}\text {-Retinal } \\
\text { dystrophy } \\
\text {-Strabismus }\end{array}$ & - &. & - & \multicolumn{2}{|c|}{$\begin{array}{l}\text {-Microphtalmia. } \\
\text {-Axial hypotonia. } \\
\text {-Intrauterine growth } \\
\text { retardation. } \\
\text { IV10- Bilateral } \\
\text { cryptorchidism } \\
\text { operated. }\end{array}$} & - & $\begin{array}{l}\text {-Alteration of the } \\
\text { pigment } \\
\text { epithelium. } \\
\text {-Leucorea } \\
\text {-Decreased visual } \\
\text { acuity. }\end{array}$ \\
\hline
\end{tabular}

MR: Mental Retardation, MRI: Magnetic Resonance Image, N: normal, -: no other features

Age of $M R=$ age of the patient at the first time referred to our department. 


\section{DNA amplification and sequencing}

All exons and intron-exon junctions of the four genes: LIM2 (4 exons), PAX6 (14 exons), PITX3 (4exons), HSF4 (13 exons) were amplified from genomic DNA by polymerase chain reaction (PCR) using primers chosen by Primer3 (Primer3-web/hldocs/inpat-040.htm).

The genes sequences were retrieved from the Ensembl database; (ENST00000221973 for LIM2/ENST00000 419022 for PAX6/ENST00000370002 for PITX3 and ENST00000264009 for HSF4).

The amplification reactions were performed by using $100 \mathrm{ng}$ of each patients' genomic DNA as a template, 20 pmol of each primer (Biomatik, Canada), a $\mathrm{MgCl}_{2}$ concentration depending upon the exon amplified, 1.5 Units of Taq DNA polymerase recombinant (Invitrogen, Carlsbad), and $1.25 \mathrm{mM}$ dNTP (Promega, Madison) in a total volume of $50 \mu \mathrm{l}$. PCR consisted on 35 cycles and was carried out in an automated thermal cycle GeneAmp PCR System 9700 (Applied Biosystems, Foster city) under the following conditions: $95^{\circ} \mathrm{C}$ for $5 \mathrm{~min}, 95^{\circ} \mathrm{C}$ for $30 \mathrm{~s}$, then $52-60^{\circ} \mathrm{C}$ for $30 \mathrm{~s}$, and elongation at $72^{\circ} \mathrm{C}$ for $30 \mathrm{~s}$, followed by one cycle of extension at $72^{\circ} \mathrm{C}$ for 7 min.

The amplified products were purified (Wizard ${ }^{\circledR}$ SV Gel and PCR Clean-Up System Kit; Promega) and sequenced (Big Dye Terminator Cycle Sequencing Ready Reaction; DNA Sequencing Kit; ABI PRISM 3130) in the forward and reverse directions. Sequencing results were visualized and data were computer analyzed using Sequencing Analysis 5.2 and SeqScape softwares (Applied Biosystems, Foster City).

\section{Results}

Screening of nine affected siblings from four Tunisian families for LIM2, PAX6, PITX3 and HSF4 pathogenic mutations revealed no mutation in the corresponding exons of each gene.

For LIM2 gene (exon 1 is an UTR for non-translated region), sequence analysis showed novel intronic changes involving modifications: IVS2 $-24 \mathrm{~A}>\mathrm{G}$ in intron 2 ; IVS $4+32 \mathrm{C}>\mathrm{T}$ in intron 4 ; c. ${ }^{* 15} \mathrm{~A}>\mathrm{C}$ in 3 ' downstream sequence. All affected and unaffected individuals were homozygous for the modified alleles.

The same for PAX6 gene, in that we detected novel intronic variations entailing: IVS4 -274insG in intron 4, IVS12 -174G $>\mathrm{A}$ in intron 11, identified in all four families and IVS4 -195G $>$ A in intron 4 identified only in families F3 and F4 (we considered the isoform PAX6 (+5a) for mutation nomenclature).

For PITX3 gene, we identified two substitutions polymorphisms in family F1: an already reported silent polymorphism, c.439C $>\mathrm{T}$ single nucleotide polymorphism (SNP rs2281983), in exon 3 that conserved the same amino acid Isoleucine (I) in the protein sequence p.
195I. Another unreported variation c.930C >A in exon 4, resulting in a proline to leucine substitution at position 258 of the protein. These two exonic changes are not included in a conserved domain of PITX3 (we considered the first nucleotide of the cDNA sequence nucleotide number one).

And for HSF4 gene, we revealed one novel intronic variation; IVS7 $+93 \mathrm{C}>\mathrm{T}$ in intron 7 detected only in family F1.

The variations identified in these four screened genes did not segregate with the phenotypes (ARCC, MR and ARCC, MR and microcephaly) because of the absence of correlation between genotypes (homozygous/heterozygous) and autosomal recessive inheritance of such studied phenotypes in the four pedigrees (Table 2).

For each novel variation identified in the four studied genes, 50 normal unrelated controls were screened and results are indicated in table 3.

Concerning LIM2 and PAX6 genes, control samples were either heterozygous or homozygous for the variable alleles which confirmed the fact that these variations did not segregate with the studied phenotype in the four families.

But for PITX3 and HSF4 genes although variations were absent in 50 ethnically matched control samples, there is no segregation between these detected polymorphisms and the studied phenotype (association between congenital cataract, mental retardation and microcephaly) in family F1.

\section{Discussion}

Congenital cataracts are common major abnormalities of the eye, which frequently cause blindness in infants [24]. It may occur as an isolated anomaly, as part of generalized ocular development defects, or as a component of a multisystem disorder [24]. In fact, association of cataract with congenital anomalies, mental retardation and microcephaly is reported in several cases with chromosomal anomalies and syndromes from genic origins [25-27].

Until today no candidate gene has been reported responsible for such phenotypes: association between congenital cataract, MR and congenital cataract, MR and microcephaly, so we tried to focus on genes already described in ADCC and/or ARCC and expressed in the human brain (PAX6, PITX3 and HSF4). And we chose to investigate the role of LIM2 gene in such phenotypes regarding the interaction between the proteins MP20 and galectin-3 in lens fiber cell.

MP20, a member of the tetraspanin superfamily, is the most abundant integral membrane protein of lens fiber cells, which appears to be distributed uniformly in the plasma membrane but also occurs in distinct membrane junctional domains early during embryonal development 
Table 2 Polymorphic changes identified in PAX6, PITX3 and HSF4 genes in the studied patients from the four Tunisian families (F1, F2, F3, and F4)

\begin{tabular}{|c|c|c|c|c|c|c|c|}
\hline \multirow[t]{2}{*}{ Familles } & \multirow[t]{2}{*}{ Patients } & \multicolumn{3}{|c|}{ PAX6 intronic variations } & \multicolumn{2}{|c|}{ PITX3 subtitution polymorphisms } & \multirow{2}{*}{$\begin{array}{l}\text { HSF4 intronic variation } \\
\text { IVS7 }+93 \mathrm{C}>\mathrm{T}\end{array}$} \\
\hline & & IVS4 -274insG & IVS12 -174G >A & IVS4 -195G>A & c.439 C>T (exon 3) & c.930 C>A (exon 4) & \\
\hline \multirow[t]{4}{*}{ F1 } & 1119 & homozygous & heterozygous & wild type & heterozygous & heterozygous & heterozygous \\
\hline & IV13 & homozygous & homozygous & wild type & heterozygous & heterozygous & heterozygous \\
\hline & IV14 & homozygous & homozygous & wild type & wild type & heterozygous & wild type \\
\hline & IV16 & homozygous & homozygous & wild type & wild type & heterozygous & wild type \\
\hline \multirow[t]{5}{*}{ F2 } & 11119 & homozygous & heterozygous & wild type & wild type & wild type & wild type \\
\hline & 11120 & homozygous & homozygous & wild type & wild type & wild type & wild type \\
\hline & IV35 & homozygous & homozygous & wild type & wild type & wild type & wild type \\
\hline & $\mathrm{V}_{36}$ & homozygous & homozygous & wild type & wild type & wild type & wild type \\
\hline & IV37 & homozygous & homozygous & wild type & wild type & wild type & wild type \\
\hline \multirow[t]{4}{*}{ F3 } & 1119 & homozygous & heterozygous & heterozygous & wild type & wild type & wild type \\
\hline & 11110 & homozygous & heterozygous & heterozygous & wild type & wild type & wild type \\
\hline & $\mathrm{IV} 11$ & homozygous & heterozygous & wild type & wild type & wild type & wild type \\
\hline & IV12 & homozygous & heterozygous & heterozygous & wild type & wild type & wild type \\
\hline \multirow[t]{4}{*}{ F4 } & 11117 & homozygous & heterozygous & heterozygous & wild type & wild type & wild type \\
\hline & 1118 & homozygous & heterozygous & heterozygous & wild type & wild type & wild type \\
\hline & IV10 & homozygous & wild type & homozygous & wild type & wild type & wild type \\
\hline & IV11 & homozygous & heterozygous & heterozygous & wild type & wild type & wild type \\
\hline
\end{tabular}

[9,28-30].Mutations in MP20 severely disrupt normal crystalline fiber cell arrangement in the lens and cause cataractogenesis $[7,8,31]$. Tetraspanins form contacts with other cells or the extracellular matrix by binding to other tetraspanins, to adhesion receptors such as integrins, and to extracellular proteins [32-34]; in this context, recently MP20 and galectin-3 were identified to colocalize in selected areas of the cell plasma membrane and biochemical analysis confirmed that MP20 and galectin-3 interact with each other [11]. In fact, galectin3 is a multifunctional protein, which occurs early during embryonal development, with reported involvement in development, oncogenesis, and inflammation [35]. It was found to be expressed by microglial cells [12], detected in a number of astrocytes in adult rat brain [36] and leads to injury in the deep gray matter areas of the brain [13]. In addition, LIM2 has been implicated in autosomal recessive cataract and reported for the first time on 2002 by Pras and co-workers [7]. By sequencing of LIM2, they revealed a Phe105Val mutation leading to a phenotype with a late-onset of cataract characterised by nuclear opacities, mild to moderate visual loss in three affected sibs whose healthy brother showed mental retardation with clear lens. On 2008, a second mutation Gly154Glu was reported by Ponnam and co-workers [8] in a phenotype involving congenital cataracts with severe visual impairment indicated by the presence of nystagmus and amblyopia but also with no sign of MR.

For PAX6 gene, it was first described as a candidate for human aniridia and ADCC but not for ARCC [37]. PAX6 expression is not restricted to the eye and appears to be crucial for brain development [38]. In order to elucidate this hypothesis, Dansault et al. [39] reported 14 affected members carrying a p.S74G mutation in

Table 3 Frequency of the novel SNPs, identified in the four screened genes, on $\mathbf{5 0}$ normal controls

\begin{tabular}{|c|c|c|c|c|}
\hline \multicolumn{2}{|c|}{ Gene/Variation } & \multirow{2}{*}{$\begin{array}{l}\text { Homozygous (for the variation) } \\
11(22 \%)\end{array}$} & \multirow{2}{*}{$\begin{array}{l}\text { Heterozygous (for the variation) } \\
0\end{array}$} & \multirow{2}{*}{$\frac{\text { Wild type }}{39(78 \%)}$} \\
\hline & IVS2 -24A>G & & & \\
\hline \multirow[t]{3}{*}{ LIM2 } & IVS4 +32C>T & $39(78 \%)$ & $11(22 \%)$ & 0 \\
\hline & C.* $15 A>C$ & $35(70 \%)$ & 15 (30\%) & 0 \\
\hline & IVS4 -274insG & $46(92 \%)$ & $4(8 \%)$ & 0 \\
\hline \multirow[t]{2}{*}{ PAX6 } & IVS12 -174G>A & 0 & $9(18 \%)$ & 41 (82\%) \\
\hline & IVS4 -195G>A & $11(22 \%)$ & $25(50 \%)$ & $14(28 \%)$ \\
\hline PITX3 & c.930C>A (exon 4) & 0 & 0 & $50(100 \%)$ \\
\hline HSF4 & IVS7 +93C>T & 0 & 0 & $50(100 \%)$ \\
\hline
\end{tabular}


exon 6 of PAX6 gene. All of them were suffering from diverse congenital ocular abnormalities including congenital cataracts, diverse neurological manifestations and variable cognitive impairments. Recently, Chien et al. [40] had identified a p.R317X PAX6 mutation in a patient (familial case) suffering from cataract, aniridia, nystagmus and was developmentally delayed. So these two reports proved that the PAX6 gene has a key role as a master regulator in the development of the eye and central nervous system.

As for PITX3, it was demonstrated to cause cataract and anterior segment mesenchymal dysgenesis (ASMD) in several families from different ethnic origins $[41,42]$. It has been described only in ADCC but not in ARCC [43]. Recently, Bidinost and coworkers (2006) reported one large Lebanese family where patients with a heterozygous mutation in PITX3 (650delG) had posterior polar cataracts (PPCs), while patients with the same mutation but with the homozygous state had a more severe ocular effect with severe microphthalmia associated with developmental delay and mental retardation. In addition, the two homozygous brothers are offspring of a consanguineous marriage, and their parents, who presented with PPCs, were examined through the 28 affected members and were heterozygous for the reported deletion. The neurologic phenotype of the homozygous patients implies an essential role for PITX3 in normal ocular and central nervous system development and this was the first report in which a potential new role of PITX3 in the development of the nervous system has been proved.

The last studied gene is HSF4 which was identified sufficiently important to lens development $[44,45]$ and disruption of the HSF4 gene leads to both autosomal dominant and ARCC (11-13). Bu et al. [18] reported, on 2002, four different missense mutations, within the HSF4 DNA binding domain, in patients with autosomal dominant lamellar and Marner cataracts from a large Chinese family. On 2004, Smaoui et al. [19] reported for the first time a HSF4 homozygous splice mutation in intron $12($ c. $1327+4 \mathrm{~A}>\mathrm{G})$ causing the skipping of exon 12 and leading to the installation of ARCC in a consanguineous Tunisian family. Then, Sajjad and coworkers [20] identified a novel HSF4 gene mutation (p.R405X) causing ARCC in a large consanguineous family from Pakistan. In the human, HSF4 is widely expressed, especially in the brain, heart, skeletal muscle, lung and pancreas [22,23].

Taking these results further, we analysed LIM2, PAX6, PITX3 and HSF4 genes in four consanguineous Tunisian families with nine affected patients showing ARCC, MR for two brothers from F2 and ARCC, MR and microcephaly for the seven other patients belonging to the four families, but we did not identify any pathogenic mutation.
Only novel intronic variations; IVS2 $-24 \mathrm{~A}>\mathrm{G}$, IVS4 $+32 \mathrm{C}>\mathrm{T}$, c. ${ }^{*} 15 \mathrm{~A}>\mathrm{C}$ detected in LIM2 gene, IVS4 -274insG, IVS12 -174G $>$ A, IVS4 -195G >A identified in PAX6 gene and IVS7 +93C $>\mathrm{T}$ in HSF4 gene. And substitution polymorphisms; a reported one c.439 C>T (rs2281983) and a novel SNP c.930 C>A revealed respectively in exons 3 and 4 of PITX3 gene. These modifications did not segregate with studied phenotypes (ARCC, MR and ARCC, MR and microcephaly).

These findings did not exclude the role of LIM2, PAX6, PITX3 and HSF4 gene in both ocular and central nervous system but it underlined the fact that these transcription factors (PAX6, PITX3), heat-shock transcription factor (HSF4) and lens intrinsic membrane protein (LIM2) could not be responsible for the association between ARCC, MR and ARCC, MR and microcephaly in the four studied Tunisian families in spite of their expression in the human brain (PAX6, PITX3, $H S F 4$ ) or their interaction with proteins expressed in human brain (LIM2).

\section{Conclusion}

In conclusion, a genome wide scan must be performed for these four families in order to identify candidate regions so that candidate gene(s) leading to such association.

\section{List of abbreviations}

We use ARCC for autosomal recessive congenital cataract, MR for mental retardation, PAX6 for Paired box homeotic gene 6, PITX3 for Pituitary homeobox gene 3, HSF4 for Heat-shock transcription factor 4, LIM2 for lens intrinsic membrane protein-2 and ADCC for autosomal dominant congenital cataract.

\section{Acknowledgements}

The authors thank all the patients and their family members for participating in the project. This study was supported by laboratory of human genetics Faculté de Médecine de Tunis, ministry of higher education and scientific research and technology and congenital and hereditary service of Charles Nicolle's hospital in Tunisia

\section{Author details}

'University Tunis Elmanar, Faculté de Médecine de Tunis, Laboratoire Génétique Humaine, Tunis, Tunisia. ${ }^{2}$ Congenital and Hereditary Disorders Department, Charles Nicolle hospital, Tunis, Tunisia. ${ }^{3}$ Department of Neonatology, Military hospital, Tunis, Tunisia. ${ }^{4}$ Opthalmology Department, Habib Thameur hospital, Tunis, Tunisia.

\section{Authors' contributions}

MC carried out thechoice of genes, the molecular genetic study, the sequence alignement and drafted the manuscript, $\mathbf{M y C}$ participated in the choice of the gene, FM carried out the examination of the patients, $\mathbf{H B}$ : participated in the clinical study of the patients, $\mathbf{A K}$ : carried out the ophthalmologic examination of the other patients and $\mathbf{H B C}$ conceived of the study, and participated in its design and coordination and helped to draft the manuscript.

All authors read and approved the final manuscript.

\section{Competing interests}

The authors declare that they have no competing interests. 
Received: 5 April 2011 Accepted: 21 November 2011

Published: 21 November 2011

\section{References}

1. Hejtmancik JF, Smaoui N: Molecular genetics of cataract. Dev Ophthalmol 2004, 37:67-82.

2. Hejtmancik JF: Congenital cataracts and their molecular genetics. Semin Cell Dev Biol 2008, 19:134-49.

3. Francis PJ, Berry V, Bhattacharya SS, Moore AT: The genetics of childhood cataract. J Med Genet 2003, 37:481-488.

4. Graw J: Congenital hereditary cataracts. Int J Dev Biol 2004, 8:1031-1044.

5. Reddy MA, Francis PJ, Berry V, Bhattacharya SS, Moore AT: Molecular genetic basis of inherited cataract and associated phenotypes. Sur Ophthalmol 2004, 49:300-315.

6. Graw J: The genetic and molecular basis of congenital eye defects. Nat Rev Genet 2003, 4:876-888.

7. Pras E, Levy-Nissenbaum E, Bakhan T, Lahat H, Assia E, Geffen-Carmi N, Frydman M, Goldman B, Pras E: A missense mutation in the LIM2 gene is associated with autosomal recessive presenile cataract in an inbred Iraqi Jewish family. Am J Hum Genet 2002, 70:1363-7.

8. Ponnam S, Ramesha K, Tejwani S, Matalia J, Kannabiran C: A missense mutation in LIM2 causes autosomal recessive congenital cataract. Mol Vis 2008, 14:1204-1208.

9. Tenbroek $E$, Arneson $M$, Jarvis $L$, Louis $C$ : The distribution of the fiber cell intrinsic membrane proteins MP20 and connexin46 in the bovine lens. J Cell Sci 1992, 103:245-57.

10. Taylor V, Welcher AA, Program AE, Suter U: Epithelial membrane protein-1, peripheral myelin protein 22 , and lens membrane protein 20 define a novel gene family. J Biol Chem 1995, 270:28824-33.

11. Gonen T, Grey AC, Jacobs MD, Donaldson PJ, Kistler J: MP20, the second most abundant lens membrane protein and member of the tetraspanin superfamily, joins the list of ligands of galectin-3. BMC Cell Biol 2001, 2:17.

12. Walther M, Kuklinski S, Pesheva P, Guntinas-Lichius O, Angelov DN, Neiss WF, Asou H, Probstmeier R: Galectin-3 is upregulated in microglial cells in response to ischemic brain lesions, but not to facial nerve axotomy. J Neurosci Res 2000, 61:430-435.

13. Doverhag C, Hedtjärn M, Poirier F, Mallard C, Hagberg H, Karlsson A Sävman K: Galectin-3 contributes to neonatal hypoxic-ischemic brain injury. Neurobiol Dis 2010, 38:36-46.

14. Hanson IM, Fletcher JM, Jordan T, Brown A, Taylor D, Adams RJ, Punnett $\mathrm{HH}$, van Heyningen $\mathrm{V}$ : Mutations at the Pax6 locus are found in heterogeneous anterior segment malformations including Peters' anomaly. Nature Genet 1994, 6:168-173.

15. Epstein J, Cai J, Glaser T, Jepeal L, Maas R: Identification of a Pax paired domain recognition sequence and evidence for DNA-dependent conformational changes. J Biol Chem 1994, 269:8355-61.

16. He W, Tuck-Muller CM, Martínez JE, Li S, Rowley ER, Wertelecki W: Molecular characterization of a ring chromosome 16 from a patient with bilateral cataracts. Am J Med Genet 2000, 107:12-7.

17. Smidt MP, Smits SM, Burbach JP: Homeobox gene Pitx3 and its role in the development of dopamine neurons of the substantia nigra. Cell Tissue Res 2004, 318:35-43.

18. Bu L, Jin $Y$, Shi $Y$, Chu $R$, Ban $A$, Eiberg $H$, Andres $L$, Jiang $H$, Zheng $G$, Qian M, Cui B, Xia Y, Liu J, Hu L, Zhao G, Hayden MR, Kong X: Mutant DNA-binding domain of HSF4 is associated with autosomal dominant lamellar and Marner cataract. Nat Genet 2002, 31:276-8.

19. Smaoui N, Beltaief O, BenHamed S, M'Rad R, Maazoul F, Ouertani A, Chaabouni H, Hejtmancik JF: A homozygous splice mutation in the HSF4 gene is associated with an autosomal recessive congenital cataract. Invest Ophthalmol Vis Sci 2004, 458:2716-21.

20. Sajjad N, Goebel I, Kakar N, Cheema AM, Kubisch C, Ahmad J: A novel HSF4 gene mutation ( $\mathrm{p} . \mathrm{R} 405 \mathrm{X}$ ) causing autosomal recessive congenital cataracts in a large consanguineous family from Pakistan. BMC Med Genet 2008, 9:99.

21. Forshew $T$, Johnson CA, Khaliq S, Pasha S, Willis C, Abbasi R, Tee L, Smith $U$, Trembath RC, Mehdi SQ, Moore AT, Maher ER: Locus heterogeneity in autosomal recessive congenital cataracts: linkage to $9 q$ and germline HSF4 mutations. Hum Genet 2005, 117:52-9.

22. Nakai A, Tanabe M, Kawazoe $Y$, Inazawa J, Morimoto Rl, Nagata K: HSF4: a new member of the human heat shock factor family which lacks properties of a transcriptional activator. Mol Cell Biol 1997, 17:469-481.
23. Tanabe M, Sasai N, Nagata K, Liu XD, Liu PC, Thiele DJ, Nakai A: The mammalian HSF4 gene generates both an activator and a repressor of heat shock genes by alternative splicing. J Biol Chem 1999, 274:27845-27856.

24. He W, Li S: Congenital cataract: gene mapping. Hum Genet 2000, 106:1-13.

25. He W, Tuck-Muller CM, Martínez JE, Li S, Rowley ER, Wertelecki W: Molecular characterization of a ring chromosome 16 from a patient with bilateral cataracts. Am J Med Genet 2002, 107:12-7.

26. Finelli $P$, Cavalli $P$, Giardino D, Gottardi G, Natacci F, Savasta S, Larizza L: FISH characterization of a supernumerary $r(1)(:: c e n->q 22:: q 22->s q 21::)$ chromosome associated with multiple anomalies and bilateral cataracts. Am J Med Genet 2001, 104:157-64.

27. Dilli D, Oğuz SS, Dilmen U, Cakar ES, Tunay ZO, Tök O, Acar MA: Congenital cataract with de novo balanced reciprocal $\mathrm{t}(3 ; 13)(\mathrm{q} 23 ; q 12)$ translocation in a newborn. J Perinat Med 2009, 37:717-9.

28. Louis CF, Hur KC, Galvan AC, Tenbroek EM, Jarvis LJ, Eccleston ED, Howard JB: Identification of an 18,000 Dalton protein in mammalian lens fiber cell membranes. J Biol Chem 1989, 264:19967-19973.

29. Arneson ML, Louis CF: Structural arrangement of lens fiber cell plasma membrane protein MP20. Exp Eye Res 1998, 66:495-509.

30. Zhou L, Chen T, Church RL: Temporal expression of three mouse lens fiber cell membrane protein genes during early development. Mol Vis 2002, 8:143-8.

31. Steele EC Jr, Kerscher S, Lyon MF, Glenister PH, Favor J, Wang J, Church RL: Identification of a mutation in the MP19 gene, Lim2, in the cataractous mouse mutant To3. Mol Vis 1997, 3:5-14.

32. Benstein E: Selective tetraspan-integrin complexes (CD81/alpha 4 beta 1, CD151/alpha 3 beta 1, CD151/alpha6 beta 1) under conditions disrupting tetraspan interactions. Biochem J 1999, 40:103-111.

33. Nakamura K, Iwamoto R, Mekada E: Membrane anchored heparin binding EGF like growth factor (Hb-EGF) and diphtheria toxin receptor associated protein (DRAP27)/CD9 form a complex with integrin a3 $\beta 1$ at cell-cell contact sites. J Cell Biol 1995, 129:1691-1705.

34. Nermut MV, Eason P, Hirst R, Kellie S: Cell substratum adhesion in RSV transformed rat fibroblasts. Exp Cell Res 1991, 193:382-397.

35. Perillo NL, Marcus ME, Baum LG: Galectins: versatile modulators of cell adhesion, cell proliferation, and cell death. J Mol Med 1998, 76:402-412.

36. Yan YP, Lang BT, Vemuganti R, Dempsey RJ: Galectin-3 mediates postischemic tissue remodeling. Brain Res 2009, 1288:116-124.

37. Villarroel CE, Villanueva-Mendoza C, Orozco L, Alcántara-Ortigoza MA, Jiménez DF, Ordaz JC, González-del Angel A: Molecular analysis of the PAX6 gene in Mexican patients with congenital aniridia: report of four novel mutations. Mol Vis 2008, 14:1650-8.

38. Glaser T, Jepeal L, Edwards JG, Young SR, Favor J, Maas RL: PAX6 gene dosage effect in a family with congenital cataracts, aniridia, anophthalmia and central nervous system defects. Nat Genet 1994, 7:463-71.

39. Dansault A, David G, Schwartz C, Jaliffa C, Vieira V, de la Houssaye G, Bigot K, Catin F, Tattu L, Chopin C, Halimi P, Roche O, Van Regemorter N, Munier F, Schorderet D, Dufier JL, Marsac C, Ricquier D, Menasche M, Penfornis A, Abitbol M: Three new PAX6 mutations including one causing an unusual ophthalmic phenotype associated with neurodevelopmental abnormalities. Mol Vis 2007, 13:511-23.

40. Chien $\mathrm{YH}$, Huang HP, Hwu WL, Chien YH, Chang TC, Lee NC: Eye anomalies and neurological manifestations in patients with PAX6 mutations. Mol Vis 2009, 15:2139-45.

41. Semina EV, Ferrell RE, Mintz-Hittner HA, Bitoun P, Alward WL, Reiter RS, Funkhauser C, Daack-Hirsch S, Murray JC: A novel homeobox gene PITX3 is mutated in families with autosomal-dominant cataracts and ASMD. Nat Genet 1998, 19:167-70

42. Berry $V$, Yang Z, Addison PK, Francis PJ, lonides A, Karan G, Jiang L, Lin W, Hu J, Yang R, Moore A, Zhang K, Bhattacharya SS: Recurrent 17 bp duplication in PITX3 is primarily associated with posterior polar cataract (CPP4). J Med Genet 2004, 41:e109.

43. Chograni M, Chaabouni M, Chelly I, Helayem MB, Chaabouni-Bouhamed $\mathrm{H}$ : Absence of PITX3 mutation in a Tunisian family with congenital cataract and mental retardation. Mol Vis 2010, 16:582-5.

44. Bidinost C, Matsumoto M, Chung D, Salem N, Zhang K, Stockton DW Khoury A, Megarbane A, Bejjani BA, Traboulsi El: Heterozygous and homozygous mutations in PITX3 in a large Lebanese family with 
posterior polar cataracts and neurodevelopmental abnormalities. Invest Ophthalmol Vis Sci 2006, 47:1274-80.

45. Shi X, Cui B, Wang Z, Weng L, Xu Z, Ma J, Xu G, Kong X, Hu L: Removal of Hsf4 leads to cataract development in mice through down-regulation of gamma S-crystallin and Bfsp expression. BMC Mol Biol 2009, 10:10.

Pre-publication history

The pre-publication history for this paper can be accessed here: http://www.biomedcentral.com/1471-2415/11/35/prepub

doi:10.1186/1471-2415-11-35

Cite this article as: Chograni et al:: Absence of mutations in four genes encoding for congenital cataract and expressed in the human brain in Tunisian families with cataract and mental retardation. BMC

Ophthalmology 2011 11:35.

Submit your next manuscript to BioMed Central and take full advantage of:

- Convenient online submission

- Thorough peer review

- No space constraints or color figure charges

- Immediate publication on acceptance

- Inclusion in PubMed, CAS, Scopus and Google Scholar

- Research which is freely available for redistribution

Submit your manuscript at www.biomedcentral.com/submit 